УДК 657:656

Бурдик О. Ю.,

olenatka@ukr.net, ORCID ID: 0000-0002-3002-7672,

аспірантка, Львівський торговельно-економічний університет, м. Львів

\title{
ОСНОВНІ ПРИНЦИПИ УПРАВЛІННЯ ВАРТІСТЮ АВТОТРАНСПОРТНОГО ПІДПРИЕМСТВА
}

\begin{abstract}
Анотація. У статті розглянуто основні принципи управління вартості автотранспортного підприємства та методичні підходи оцінки його вартості. Акцентовано увагу на важливості управлінського обліку та інформаційного забезпечення, як його складової, у визначенні вартості автотранспортного підприємства. Зазначено про обов'язковість аналізу фінансового стану підприємства, оскільки він чітко розкриває всі ризики $і$ перспективи його діяльності. Мета статті - визначити та розглянути основні принципи управління вартістю підприємства, з урахуванням виду діяльності - міські пасажирські перевезення, комунальної форми власності. Вартість підприємства оцінює його діяльність коли стоїть завдання продажу підприємства чи здійснення інвестиційних вкладень. Інформація щчодо вартості иікавить менеджерів та власника підприємства, інвесторів. Хоч очінка вартості підприємства здійснюється здебільшого для підприємств приватної форми власності, на нашу думку, вона є важливою і для підприємств комунальної форми власності, оскільки діяльність підприємств вже тривалий час здійснюється «на мінус» та необхідно залучати інноваційні підходи щзодо управлінської діяльності підприємства. Не вирішеною проблемою залишається неналежний рівень розробки та впровадження методичних підходів визначення вартості підприємства, про шо зазначено багатьма вченими. Проаналізувавши зміст оцінки вартості підприємства та методичні підходи можна зробити висновок, що ие комплексний підхід, з обов 'язковим урахуванням можливості економічного зростання та негативного впливу на розвиток підприємства факторів ризику. Він є більш інформативним ніж просто дані фінансової звітності, проте потребує методичного редагування, з метою адаптації до діяльності підприємств в Украӥні. Важливою є окрема розробка та впровадження методики визначення вартості для автотранспортних підприємств комунальної форми власності. Зроблено необхідні висновки та пропозиції шодо досліджуваної теми.
\end{abstract}

Ключові слова: вартість підприємства, автотранспортне підприємство, показники фінансового стану, управління вартістю, витратний підхід.

Burdyk O.Y., olenatka@ukr.net, ORCID ID: 0000-0002-3002-7672, Postgraduate, Lviv University of Trade and Economics, Lviv

\section{BASIC PRINCIPLES OF MANAGEMENT OF A MOTOR TRANSPORT ENTERPRISE'S COST}

\begin{abstract}
The article considers the basic principles of management of a motor transport enterprise's cost and methodological approaches to estimating its cost. Emphasis is placed on the importance of managerial accounting and information support, as its component, in the determination of the motor transport enterprise's cost. It is mentioned that the analysis of the financial condition of the enterprise is obligatory, as it clearly reveals all the risks and prospects of its activity. The purpose of the article is to define and consider the basic principles of management of enterprise's cost, taking into account the type of activity - urban passenger transportation, communal ownership. The cost of the enterprise evaluates its activities when the task is to sell the enterprise or make investments. Information on the cost is of interest to managers and owner of the enterprise as well as to investors. Although the assessment of the enterprise's cost is carried out mainly for privately owned enterprises, in our opinion, it is important for communal enterprises, as the activities of enterprises have long been carried out "at minus" and it is necessary to introduce innovative approaches for its management. As noted by many scientists, an unsolved problem is the inadequate level of development and implementation of methodical approaches to determining the enterprise's cost. After analyzing the content of the assessment of the enterprise's cost and methodical approaches, we can conclude that - this is a comprehensive approach, considering the possibility of economic growth and the negative impact of risk factors on the development of the enterprise. It is more informative than just financial reporting data, but it needs methodical editing in order to adapt to the activities of enterprises in Ukraine. It is important to develop and implement a separate method of determining the cost of communal motor transport enterprises. Necessary conclusions and suggestions on the researched topic are made.
\end{abstract}

Key words: enterprise's cost, motor transport enterprise, indicators of financial condition, cost management, cost approach.

JEL Classification: D23, M14, L97, R40

DOI: https://doi.org/10.36477/2522-1205-2021-62-18 


\section{Herald of Lviv University of Trade and Economics. Economic Sciences. № 62, 2021}

Постановка проблеми. Оскільки на сьогоднішній день питання збитковості пасажирських міських автотранспортних перевезень так і залишається невирішеним, необхідно розглядати дану проблему як багатогранну, адже вона складається 3 багатьох чинників. Важливе місце у вирішенні даної проблеми посідає питання якісного управління вартістю підприємства, тому що вона $є$ своєрідним індикатором фінансового стану підприємства, формуючи узагальнену інформацію фінансових показників АТП, та є невід'ємною частиною управлінського обліку.

Аналіз останніх досліджень і публікацій. Питанню вартості підприємства приділяли увагу такі вчені, як Г. І. Міокова, М. Г. Чумаченько, О. Г. Мендрул, О. В. Брезіцька, В. Н. Гавва, О. О. Терещенко, О. Б. Мних, С. І. Тарасенко, В. І. Куцик, М. В. Корягін. Однак, враховуючи важливість розкриття змісту даного питання та специфіку діяльності саме міських автотранспортних пасажирських перевезень, вважаємо доцільним проведення подальших досліджень у даному напрямку.

Постановка завдання. Мета статті - визначити та розглянути основні принципи управління вартістю підприємства, з урахуванням виду діяльності - міські пасажирські перевезення комунальної форми власності. Зробити необхідні висновки та пропозиції щодо досліджуваної теми.

Виклад основного матеріалу дослідження. Часто вартість підприємства ототожнюють із вартістю бізнесу, оцінюючи його діяльність 3 метою продажу підприємства чи здійснення інвестиційних вкладень. Інформація щодо вартості цікавить менеджерів та власника підприємства, інвесторів. Хоч оцінка вартості підприємства здійснюється здебільшого для підприємств приватної форми власності, на нашу думку, вона $\epsilon$ важливою і для підприємств комунальної форми власності, оскільки діяльність підприємств вже тривалий час здійснюється "на мінус" та необхідно залучати інноваційні підходи щодо управлінської діяльності підприємства. Адже вартість підприємства зростатиме за умови якісного управління ним, i, як наслідок, збільшення вартості підприємства буде свідчити про позитивну динаміку діяльності підприємства. Важливим $\epsilon$ проведення оцінки вартості діяльності підприємства для правильної побудови стратегії розвитку. Наприклад, оцінка інвестиційної діяльності автотранспортного підприємства полягає у закупівлі нових одиниць рухомого складу автопарку.

Основними принципами управління вартістю підприємства, на нашу думку, повинні бути:

- оцінка вартості підприємства;

- розробка стратегії збільшення вартості підприємства;

- складання фінансового плану, спрямованого на фінансування даної стратегії;

- побудова бюджетів підприємства;

- контроль за виконанням стратегії;

- $\quad$ здійснення аналізу динамічних змін у вартості підприємства;
- ведення внутрішньоуправлінського обліку відповідно до здійсненого аналізу.

Згідно з Постановою Кабінету Міністрів України [2] на сьогодні передбачено застосування таких методичних підходів оцінки вартості підприємства: - витратний (майновий);

- дохідний;

- порівняльний.

Витратним підходом передбачено визначення поточної вартості витрат методом прямого відтворення або методом заміщення. Даний методичний підхід ефективно застосовувати для підприємств, де отримання прибутку не очікується.

Дохідний підхід передбачено для прибуткових підприємств, оскільки він визначає поточну вартість доходів, які очікуються. В залежності від наявної інформації стосовно прогнозованих доходів оцінюваного об'єкта існує поділ на методи прямої капіталізації доходу та дисконтування грошового потоку.

При застосуванні порівняльного підходу використовують аналіз цін продажу із врахуванням вартості подібного майна.

На нашу думку, для оцінки вартості автотранспортного підприємства саме комунальної форми власності, враховуючи специфіку його діяльності, доцільно використовувати витратний підхід, оскільки він найповніше характеризує фінансовий стан підприємства.

Важливу роль у визначенні вартості автотранспортного підприємства відіграє управлінський облік. Його суть полягає у налагодженні інформаційної системи, оскільки для визначення правильної вартості підприємства необхідно, щоб формувалися достовірні, чіткі та своєчасні дані. Так, науковці В. В. Бойко та Н. В. Любарська підкреслюють, що фактори вартості внутрішнього середовища $\epsilon$ результатом прийняття управлінських рішень керівництвом підприємства [7, с. 41].

Важливим $\epsilon$ інформаційне забезпечення, яке формується насамперед із фінансової звітності підприємства та коли здійснюється фінансовий аналіз. Так, Ю. О. Кульбач зазначив, що на даний час не вирішено питання щодо ефективного впровадження вартісних показників у практику фінансового управління на підприємстві [11, с. 83]. Г. В. Кириченко зазначає, що сьогодення вимагає від автотранспортних підприємств формування стратегіі, яка б була орієнтована на вартість та реалізація якої б могла відбутися за наявних можливостей підприємства в обмежений термін [9, c. 373]. А. В. Воронін акцентує увагу, що управління вартістю підприємства - це система методів впливу на внутрішні фактори підприємства зокрема та на фактори зовнішнього середовища опосередковано з метою забезпечення динамічного розвитку підприємства та підвищення його стійкості у зовнішньому середовищі, а також інвестиційної привабливості за допомогою досягнення зростання його вартості $[8$, с. 150]. Ознака успішної діяльності підприємства - підвищення обсягу пасажирських перевезень 3 мінімальною кількістю затрат, здійснених на виконання даної діяльності. 
Однією 3 умов досягнення такої мети є наявність якісного матеріально-технічного забезпечення автотранспортного підприємства, а це неможливо без залучення інвестицій (фінансування), тобто за умови збільшення вартості підприємства. С. В. Позняк та С. С. Данильченко зазначено, що актуальною і маловивченою проблемою 3 наукової точки зору є формулювання підходів до практичного застосування моделей вартісного управління залежно від етапу розвитку підприємства [13].

Невирішеною проблемою залишається неналежний рівень розробки та впровадження методичних підходів визначення вартості підприємства, про що зазначено багатьма вченими. Наприклад, I. Я. Левчак наголошує, що загальний рівень теоретико-методологічної бази 3 управління вартістю підприємством в Україні є низьким, зокрема недостатньо висвітлені аспекти ролі критерію вартості бізнесу в системі показників ефективності діяльності підприємства та можливість застосування оцінки бізнесу як інструменту стратегічного планування [12, с. 104]. В. I. Куцик, I. В. Явтуховська зазначають, що не всі загальновизнані західними методиками оцінювання підходи та методи адаптовані для використання на вітчизняних підприємствах, тому неможливо стверджувати про достовірність отриманого результату $[1$, c. 86$]$.

На даний час Порядок погодження, затвердження або прийняття оцінки майна здійснюється відповідно до Методики оцінки майна Кабінету Міністрів України [3].

Незалежно від обраного підходу визначення вартості підприємства основою для іiї правильної оцінки має бути аналіз фінансового стану підприємства, тому що він чітко розкриває всі ризики і перспективи його діяльності. Такої ж думки $є$ науковець М. В. Корягін, який вважає, що економічний аналіз виступає важливою складовою системи формування вартості підприємства та що система бухгалтерського обліку $є$ інформаційною основою для проведення аналізу показників вартості підприємства та забезпечує одержання достовірних значень показників вартості [10, c. 191], з чим ми повністю погоджуємося.

Саме від показника фінансового стану залежить коригування остаточної вартості підприємства. До основних показників фінансового стану автотранспортного підприємства слід віднести:

коефіцієнт рентабельності активів;

коефіцієнт рентабельності власного капіталу;

коефіцієнт рентабельності діяльності;

коефіцієнт фінансової стійкості;

коефіцієнт покриття;

коефіцієнт абсолютної ліквідності;

- коефіцієнт концентрації залученого капіталу.

Так, Наказом Міністерства фінансів України затверджено Методику аналізу фінансовогосподарської діяльності підприємств державного сектору економіки [4]. Згідно 3 нею коефіцієнт рентабельності активів відображає рівень ефектив- ності використаних активів. Завдяки ньому можна охарактеризувати темпи розвитку підприємства.

Свідченням прибуткової діяльності підприємства $€$ високі показники коефіцієнта рентабельності власного капіталу, який відображає частку чистого прибутку у власному капіталі.

Здатність підприємства відтворювати та розширювати виробництво відображає коефіцієнт рентабельності діяльності.

Коефіцієнт фінансової стійкості - співвідношення власних та позикових коштів, які визначають рівень фінансової стійкості та незалежності підприємства від зовнішніх фінансових джерел.

Коефіцієнт покриття відображає, чи достатньо на підприємстві оборотних засобів, щоб протягом року погасити заборгованість.

Можливість погашення поточної заборгованості підприємства наявними грошовими коштами визначає коефіцієнт абсолютної ліквідності.

Коефіцієнт концентрації залученого капіталу відображає розмір частки залученого капіталу у загальній сумі валюти балансу.

Для визначення фінансового стану ЛК АТП №1 розраховано основні його показники за 2017 2019 pр. (табл. 1).

Таблиия 1

Основні показники фінансового стану ЛК АТП №1 за 2017-2019 pp. [5, 6]

\begin{tabular}{|c|l|c|c|c|c|}
\hline \multirow{2}{*}{$\begin{array}{c}\text { № } \\
\text { з/п }\end{array}$} & Коефіцієнти & \multicolumn{3}{|c|}{ Роки } & \multirow{2}{*}{ Тенденція } \\
\cline { 2 - 5 } 1 & $\begin{array}{l}\text { Коефіцієнт } \\
\text { рентабель- } \\
\text { ності активів }\end{array}$ & 0,000 & 0,000 & 0,000 & Без змін \\
\hline 2 & $\begin{array}{l}\text { Коефіцієнт } \\
\text { рентабель- } \\
\text { ності влас- } \\
\text { ного капіталу }\end{array}$ & 0,000 & 0,000 & 0,000 & Без змін \\
\hline 3 & $\begin{array}{l}\text { Коефіцієнт } \\
\text { рентабель- } \\
\text { ності діяль- } \\
\text { ності }\end{array}$ & 0,000 & 0,000 & 0,000 & Без змін \\
\hline 4 & $\begin{array}{l}\text { Коефіцієнт } \\
\text { фінансової } \\
\text { стійкості }\end{array}$ & 0,904 & 0,838 & 0,805 & Зниження \\
\hline 5 & $\begin{array}{l}\text { Коефіцієнт } \\
\text { покриття }\end{array}$ & 0,301 & 0,397 & 0,237 & Зниження \\
\hline 6 & $\begin{array}{l}\text { Коефіцієнт } \\
\text { абсолютної } \\
\text { ліквідності }\end{array}$ & 0,139 & 0,205 & 0,149 & Зниження \\
\hline 7 & $\begin{array}{l}\text { Коефіцієнт } \\
\text { концентрації } \\
\text { залученого } \\
\text { капіталу }\end{array}$ & 0,105 & 0,392 & 0,319 & Зниження \\
\hline
\end{tabular}

Як бачимо, діяльність підприємства за досліджувані роки була збитковою, оскільки коефіцієнт рентабельності активів та коефіцієнт рентабельності власного капіталу хоча і без змін, проте нижче нормативного значення. Не відповідає нормативному значенню і коефіцієнт рентабельності 
діяльності, що унеможливлює відтворення виробництва, а от коефіцієнт фінансової стійкості відповідає встановленим нормам, тобто підприємство є фінансово відносно стійким. Коефіцієнт покриття свідчить про незадовільний стан платоспроможності автотранспортного підприємства.

Висновки і перспективи подальших досліджень у даному напрямі. Проаналізувавши зміст оцінки вартості підприємства та методичні підходи, можна зробити висновок, що це комплексний підхід, 3 обов'язковим урахуванням можливості економічного зростання та негативного впливу на розвиток підприємства факторів ризику. Він $є$ більш інформативним, ніж просто дані фінансової звітності, проте потребує методичного редагування 3 метою адаптації до діяльності підприємств в Україні. Важливими $\epsilon$ окрема розробка та впровадження методики визначення вартості для автотранспортних підприємств комунальної форми власності.

\section{ЛIТЕРАТУРА}

1. Куцик В. І. Методи та підходи до оцінки вартості підприємства: теоретичний аспект, проблеми їх використання / В. I. Куцик, I. В. Явтуховська // Вісник Львівської комерційної академії. Серія економічна. - 2015. - Вип. 48. С. 82-87 [Електронний ресурс]. - Режим доступу: http://nbuv.gov.ua/UJRN/Vlca_ekon_2015_48_16.

2. Постанова Кабінету Міністрів України від 10 вересня 2003 р. №1440 "Про затвердження Національного стандарту №1 «Загальні поняття оцінки майна й майнових прав»" (із змінами, внесеними згідно з Постановами КМ № 168 (1682015-п) від 31.03.2015).

3. Постанова Кабінету Міністрів України від 10 грудня 2003 р. №1891 “Методика оцінки майна" (в редакції постанови Кабінету Міністрів України від 20 лютого 2019 р. № 224).

4. Про затвердження Методики аналізу фінансово-господарської діяльності підприємств державного сектору економіки. Наказ Міністерства фінансів України від 14 лютого 2006 року № 170.

5. Фінансова звітність за рік, що закінчився 31 грудня 2019 року відповідно до міжнародних стандартів фінансової звітності разом зі звітом незалежного аудитора Львівського комунального автотранспортного підприємства №1 [Електронний pecypc]. - Режим доступу: https://atp1.lviv.ua/wpcontent/uploads/Finansova-zvitnist-LK-ATP-1-2019.pdf.

6. Фінансова звітність за 2017 рік ЛКП АТП №1 [Електронний ресурс]. - Режим доступу: https://opendata.city-adm.lviv.ua/dataset/finansovazvitnist-za-2017-rik-lkp-atp-1.

7. Бойко В. В. Систематизація факторів формування вартості автотранспортного підприємства / В. В. Бойко, Н. В. Любарська // Науковотехнічний збірник. - 2015. - Вип. 3 (33). - С. 39-46.

8. Воронін А. В. Системний підхід до управління вартістю підприємства / А. В. Воронін // Економіка і організація управління. - 2016. - Вип. 3 (23). - C. 148-155.
9. Кириченко Г. В. Принципи формування орієнтованої на вартість стратегії розвитку підприємства автомобільного транспорту / Кириченко Г. В. // Вісник НТУ. - К., НТУ, 2012. Вип. 26.

10. Корягін М. В. Бухгалтерський облік у системі управління вартістю підприємства: теоретико-методологічні концепції : монографія / М. В. Корягін. - Львів : Видавництво ЛКА, 2012. 389 c.

11. Кульбач Ю. О. Механізм управління вартістю підприємства / Ю. О. Кульбач // Інвестиції: практика та досвід. - 2017. - № 23. - С. 82-86 [Електронний ресурс]. - Режим доступу: http://nbuv.gov.ua/UJRN/ipd_2017_23_16.

12. Левчак I. Я. Вартість підприємства як критерій ефективності управління / І. Я. Левчак // Науковий вісник Ужгородського університету. Сер. : Економіка. - 2014. - Вип. 1. - С. 104-108 [Електронний ресурс]. - Режим доступу: http://nbuv.gov.ua/UJRN/Nvuuec_2014_1_21.

13. Позняк С. В. Управління вартістю та конкурентоспроможністю підприємства задля забезпечення його стійкого розвитку / С. В. Позняк, С. С. Данильченко // Ефективна економіка : електр. наук. фах. вид. / Дніпропетр. держ. агр.-екон. ун-т. - Електрон. текст. дані. - Дніпропетровськ, 2015. № 8 [Електронний ресурс]. - Режим доступу: http://www.economy.nayka.com.ua/?op=1\&z=4611.

\section{REFERENCES}

1. Kutsyk, V. I. and Yavtukhovs'ka, I. V. (2015), Metody ta pidkhody do otsinky vartosti pidpryiemstva: teoretychnyj aspekt, problemy ikh vykorystannia, Visnyk L'vivs'koi komertsijnoi akademii. Seriia ekonomichna., vyp. 48, s. 82-87, available at: http://nbuv.gov.ua/UJRN/Vlca_ekon_2015_48_16.

2. Postanova Kabinetu Ministriv Ukrainy vid 10 veresnia 2003 r. №1440 "Pro zatverdzhennia Natsional'noho standartu №1 «Zahal'ni poniattia otsinky majna j majnovykh prav»" (iz zminamy, vnesenymy zghidno z Postanovamy KM № 168 (1682015-p) vid 31.03.2015).

3. Postanova Kabinetu Ministriv Ukrainy vid 10 hrudnia 2003 r. №1891 "Metodyka otsinky majna" (v redaktsii postanovy Kabinetu Ministriv Ukrainy vid 20 liutoho 2019 r. № 224).

4. Pro zatverdzhennia Metodyky analizu finansovo-hospodars'koi diial'nosti pidpryiemstv derzhavnoho sektoru ekonomiky. Nakaz Ministerstva finansiv Ukrainy vid 14 liutoho 2006 roku № 170.

5. Finansova zvitnist' za rik, scho zakinchyvsia 31 hrudnia 2019 roku vidpovidno do mizhnarodnykh standartiv finansovoi zvitnosti razom zi zvitom nezalezhnoho audytora L'vivs'koho komunal'noho avtotransportnoho pidpryiemstva №1, available at: https://atp1.lviv.ua/wp-content/uploads/Finansovazvitnist-LK-ATP-1-2019.pdf.

6. Finansova zvitnist' za 2017 rik LKP ATP №1, available at: https://opendata.cityadm.lviv.ua/dataset/finansova-zvitnist-za-2017-rik-lkpatp-1. 
7. Bojko, V. V. and Liubars'ka, N. V. (2015), Systematyzatsiia faktoriv formuvannia vartosti avtotransportnoho pidpryiemstva, Naukovotekhnichnyj zbirnyk, vyp. 3 (33), s. 39-46.

8. Voronin, A. V. (2016), Systemnyj pidkhid do upravlinnia vartistiu pidpryiemstva, Ekonomika i orhanizatsiia upravlinnia, vyp. 3 (23), s. 148-155.

9. Kyrychenko, H. V. (2012), Pryntsypy formuvannia oriientovanoi na vartist' stratehii rozvytku pidpryiemstva avtomobil'noho transportu, Visnyk NTU, K., NTU, vyp. 26.

10. Koriahin, M. V. (2012), Bukhhalters'kyj oblik u systemi upravlinnia vartistiu pidpryiemstva: teoretyko-metodolohichni kontseptsii : monohrafiia, Vydavnytstvo LKA, L'viv, 389 s.

11. Kul'bach, Yu. O. (2017), Mekhanizm upravlinnia vartistiu pidpryiemstva, Investytsii: praktyka ta dosvid, № 23, s. 82-86, available at: http://nbuv.gov.ua/UJRN/ipd_2017_23_16.

12. Levchak, I. Ya. (2014), Vartist' pidpryiemstva iak kryterij efektyvnosti upravlinnia, Naukovyj visnyk Uzhhorods'koho universytetu. Ser. : Ekonomika., vyp. 1, s. 104-108, available at: http://nbuv.gov.ua/UJRN/ Nvuuec_2014_1_21.

13. Pozniak, S. V. and Danyl'chenko, S. S. (2015), Upravlinnia vartistiu ta konkurentospromozhnistiu pidpryiemstva zadlia zabezpechennia joho stijkoho rozvytku, Efektyvna ekonomika : elektr. nauk. fakh. vyd., № 8 / Dnipropetr. derzh. ahr.-ekon. un-t, Elektron. tekst. dani, Dnipropetrovs'k, available at: http://www.economy.nayka.com.ua/?op=1\&z=4611.

Стаття надійшла до редакиії 08 грудня $2020 \mathrm{p}$. 